\title{
The Effect of Addition of ZnO to Granite Body on Sintering and Mechanical Properties
}

\author{
Savaş Elmas ${ }^{1 *(\mathbb{D})}$ \\ ${ }^{1}$ Ceramic and Glass Department, Fine Arts Faculty, Çanakkale Onsekiz Mart University, Çanakkale, Turkey \\ *savaselmas@comu.edu.tr \\ *Orcid: 0000-0003-2913-0303
}

Received: 22 October 2020

Accepted: 11 March 2021

DOI: $10.18466 /$ cbayarfbe. 814870

\begin{abstract}
In granite body, 1-3-5 wt $\% \mathrm{ZnO}$ was replaced instead of feldspar and fired in an industrial continuous production kiln. Physical properties of the tiles were determined including dried strength, fired strength, water absorption, fired loss, and colorimeter values. X-Ray Diffraction (XRD), scanning electron microscope (SEM) and energy dispersive X-Ray (EDX) measurements for distinctive microstructural changes and phases formed were done. The fired strength values of the standard and $3 \% \mathrm{ZnO}$ added body are $400 \mathrm{~kg} / \mathrm{cm}^{2}, 511 \mathrm{~kg} / \mathrm{cm}^{2}$, respectively. Water absorption and firing shrinkage values are close to each other. In the analysis of the sample with $3 \%$ added $\mathrm{ZnO}$ with $\mathrm{XRD}$, it was observed that the solubility of quartz was increased, mullite formation was prevented; besides $27.4 \mathrm{wt} . \%$ spinel phase and $13.8 \mathrm{wt} . \%$ albite formation was observed.
\end{abstract}

Keywords: Ceramics, characteristics, microstructure, porcelain stoneware (granite tile), sintering, $\mathrm{ZnO}$

\section{Introduction}

In the competitive conditions increasing with globalization, efficiency and exceeding customer expectations force companies to obtain products with superior features. In ceramic production, granite tile has been in demand in recent years with its superior properties. Turkey's share in the world total in 2018 was $2.6 \%$ with 335 million $\mathrm{m}^{2}[1]$.

Many studies have been done in the literature on the production of porcelain stoneware [2-5]. Ceramic bodies consist of 3 basic raw materials. Clay gives properties such as workability, green strength, body color, rheology. Feldspars affect the solubility, the amount of the glassy phase, the viscosity and the formation temperature of the glassy phase. Quartz, with its inert structure, prevents the body from cracking during drying and deformation during firing [6-7]. The microstructure, which determines the properties of the material, includes the amount, shape and distribution of phases and pores. At the same time, the composition of the glassy phase formed, its homogeneity and the structural stress between different phases affects the properties [8]. Body undergoes some changes with its body firing. The removal of residual moisture below
$200{ }^{\circ} \mathrm{C}$, the removal of organics at $200-650{ }^{\circ} \mathrm{C}$, conversion of kaolin into metakaolin at $450-600{ }^{\circ} \mathrm{C}$, 500-600 ${ }^{\circ} \mathrm{C}$ quartz transformation, the initiation of reactions between $900-1000{ }^{\circ} \mathrm{C}$ silica and alumina, > $1000{ }^{\circ} \mathrm{C}$ eutectic formation and partial melting begins [9-11]. Liquid content increases after $1200{ }^{\circ} \mathrm{C}$ as a result of the increase in quartz solubility. Small mullite (primary) and $\gamma$-alumina crystals are formed between the degraded clay particles, while secondary mullite crystals are formed between the clay and feldspar [12]. Some oxides have been studied in the literature in the form of dopant to the vitrified body. In a study conducted by Bhattacharyya and Snehesh [13] on the subject, it was observed that the addition of $\mathrm{Cr}_{2} \mathrm{O}_{3}$ to the porcelain body in the range of $0-4$ wt.\%, negatively affected the structural properties. In the same study, it was observed that the addition of $1-5 \mathrm{wt} \% \mathrm{NiO}$, improved physical and mechanical properties at 1200 ${ }^{\circ} \mathrm{C}$. Beside the mullite, nickel aluminate spinel phase was formed. It was observed that the addition of $\mathrm{NiO}$ also affected mullite morphology. With the addition of 5 wt.\% NiO, maximum shrinkage, minimum porosity, high bulk density and maximum fired strength were observed at $1200{ }^{\circ} \mathrm{C}$. In another study conducted by Bhattacharyya and Snehesh [14] on the subject, it was observed that 1-5 wt\% $\mathrm{CoO}$ was added and gave positive results in physical and mechanical properties as 
a result of firing at $1100-1200{ }^{\circ} \mathrm{C}$. Feldspar's solubility and mullitization were increased with the addition of CoO. The addition of 1 wt. $\% \mathrm{CoO}$ has given the body optimum fired properties at low temperatures. In a study by Bhattacharya, Das and Mitra [15], $\mathrm{TiO}_{2}$ was added to the porcelain body in the range of 3-6-9 wt.\% and fired at $1200-1250-1300-1350-1400{ }^{\circ} \mathrm{C}$. It was observed that excess liquid phase was formed at temperatures above $1300{ }^{\circ} \mathrm{C}$ and as a result, swelling occurred in the product. At $1300{ }^{\circ} \mathrm{C}$, negligible porosity and maximum strength value of $45 \mathrm{MPa}$ were observed. It was determined that with increasing $\mathrm{TiO}_{2}$ amount, quartz amount decreased, mullite and liquid phase amount increased. After the 6 wt. $\% \mathrm{TiO}_{2}$ increase, no significant property change appears. In a study about the addition of $\mathrm{ZnO}$ to porcelain body (Chaudri 1974; transmited Bhattacharyya,Das and Mitra, 2005) it was observed that with the addition of $4 \% \mathrm{ZnO}$ to the porcelain body, a minimum of mullite was formed[16]. In a study conducted by Iya, Noh, Razak, Sharip and Kutty [17], it was observed that the addition of 5 wt. $\% \mathrm{Fe}_{2} \mathrm{O}_{3}$ at 1150 ${ }^{\circ} \mathrm{C}$ increased mullitization and the amount of liquid phase. Maximum strength value, bulk density and hardness values were reached to $138.94 \mathrm{MPa}, 2.515 \mathrm{~g} /$ $\mathrm{cm}^{3}, 829 \mathrm{HV}$, respectively. It has been observed that the maturing temperature is $100-120{ }^{\circ} \mathrm{C}$ lower than the standard body. The addition of $\mathrm{Fe}_{2} \mathrm{O}_{3}$ inside the porcelain body instead of quartz, the chemical analyzes of standard and $\mathrm{Fe}_{2} \mathrm{O}_{3}$ added bodies are respectively, $46.5 \%$ quartz, $35.4 \%$ aluminosilicate, $5.1 \%$ calcium, $13.1 \%$ sulfuric acid and $42 \%$ quartz, $32 \%$ mullite, $21 \%$ anorthite, $5 \%$ iron. The peaks are more precise with the addition of $\mathrm{Fe}_{2} \mathrm{O}_{3}$. By the help of the presence and interaction of anorthite and mullite crystals, bulk density and strength increased. This effect is evident especially with the addition of $5 \% \quad \mathrm{Fe}_{2} \mathrm{O}_{3}$. In a study by Tulyaganov, Agathopoulos, Fernandes and Ferreria [18] $\mathrm{Li}_{2} \mathrm{CO}_{3}$ was added to the porcelain structure at increasing rates of 1-7 wt.\%. Positive results were achieved when $\mathrm{Li}_{2} \mathrm{O}$ does not exceed 1.5 wt. $\%$. In a study by Chaudhuri and Sarkar [19], mullite formation increased in the porcelain body where $\mathrm{V}_{2} \mathrm{O}_{5}$ and $\mathrm{Nb}_{2} \mathrm{O}_{5}$ additions were $3 \%$ and $2 \%$, respectively; It has been found that they are effective nucleators for crystal formation. At the same time, while the amount of cristobalite was almost $0 \%$ among other samples, it was found to be as high as $24.8 \%$ in only $2 \% \mathrm{Nb}_{2} \mathrm{O}_{5}$ added body. In another study [20], $\mathrm{FeO}_{1.5}, \mathrm{CoO}$ and $\mathrm{NiO}$ were added and the order of reducing viscosity was seen as $\mathrm{FeO}_{1.5}>\mathrm{CoO}>\mathrm{NiO}$.

In this study, the addition of $\mathrm{ZnO}$ to the granite body was made as 1-3-5 wt.\% and firing shrinkage, water absorption, fired strength, dried strength, fired losses were determined. In addition, crystalline phases after firing were detected by X-ray analysis (XRD); surface morphology, microstructure, phase and elemental analysis were investigated using energy dispersive $\mathrm{X}$ - ray spectroscopy (EDX) and scanning electron microscopy (SEM).

\section{Materials and Methods}

The addition of $\mathrm{ZnO}$ instead of sodium feldspar in the prepared industrial body was made as $1-3-5$ wt. $\%$. The materials were prepared in the proportions specified in the recipe and at a density of $1650 \mathrm{gr} / \mathrm{lt},>63$ microns residue with $3.6 \%$. After being kept in the dryer for 810 hours at $110{ }^{\circ} \mathrm{C}$, water was added to the powder with a spray to obtain granules with a moisture value of 5$6 \%$, then these granules were pressed to $300 \mathrm{~kg} /$ $\mathrm{cm}^{2}$.Firing was carried out in an industrial continuous kiln at $1180-1185{ }^{\circ} \mathrm{C}$ in 63 minutes. Dwelling timey at the maximum temperature is 3 minutes. Chemical analysis of the raw materials used are shown in Table 1, and the prescriptions prepared are shown in Table 2 . The strength measurement was made in a 3-point gabrielli brand strength device according to equation (Eq. 2.1).

$$
\mathrm{S}=\frac{30 \cdot P}{L \cdot h^{2}}
$$

formula is used for strength $\left(\mathrm{kg} / \mathrm{cm}^{2}\right)$.

$\mathrm{S}$ : the breaking strength $\left(\mathrm{kg} / \mathrm{cm}^{2}\right)$

P: the load breaking the tile $\left(\mathrm{kg} / \mathrm{cm}^{2}\right)$

$\mathrm{L}$ : the width of the tile $(\mathrm{cm})$ and

$\mathrm{h}$ : the thickness of the tile $(\mathrm{cm})$

In the water absorption process is used equation ( Eq. 2.2) below

water absorbtion $(\%)=\frac{\left(w_{2}-w_{1}\right)}{w_{1}} \cdot 100$

$\mathrm{W}_{1}$ : dry weight

$\mathrm{W}_{2}$ : water absorbed weight ( sample was kept in boiling water for 2 hours to cool, then it was wiped with a damp cloth then weighed).

XRD measurements were made by XRD Pan Analytic Empeyron Series $45 \mathrm{kV}, \mathrm{K}$ alpha. Microstructure photos were measured by SEM-JEOL- JSM -7100 F. EDX measurements were made in Oxford Instruments $\mathrm{X}$-max quorum 1mbar / Pa, 10mA, Au / Pa (80/20\%) coating. Color measurement was made on the Minolta CR 300 instrument. Color difference measurement is made with equation ( Eq. 2.3).

$$
\Delta \mathrm{E}=\sqrt{(L 2-L 1)^{2}+(a 2-a 1)^{2}+(b 2-b 1)^{2}}
$$

$\Delta \mathrm{E}$ : criterion for detecting color difference

L: lightness value

a: redness value

b: yellowness value

$\mathrm{ZnO}$ from Tekkim Kimya extra pure grade is used. 
Table 1. Chemical analysis of used raw materials.

\begin{tabular}{|l|l|l|l|l|l|l|l|l|l|l|}
\hline & $\mathbf{S i O}_{2}$ & $\mathbf{A l}_{2} \mathbf{O}_{3}$ & $\mathbf{F e}_{2} \mathbf{O}_{3}$ & $\mathbf{T i O}_{2}$ & $\mathbf{C a O}$ & $\mathbf{M g O}$ & $\mathbf{N a}_{2} \mathbf{O}$ & $\mathbf{K}_{\mathbf{2}} \mathbf{O}$ & $\mathbf{Z n O}$ & F.L. \\
\hline Kaolin & 52 & 34.05 & 0.80 & 0.30 & 0.15 & 0.30 & 0.15 & 1.30 & - & 12 \\
\hline Albite & 69 & 19.6 & 0.017 & 0.04 & 0.95 & 0.11 & 10.30 & 0.23 & - & 0.12 \\
\hline $\begin{array}{l}\text { Quartz } \\
\text { sand }\end{array}$ & 91 & 7 & 0.8 & 0.3 & 0.02 & 0.02 & & 0.76 & - & 0.1 \\
\hline Clay & 54 & 31.05 & 0.67 & 1.17 & 0.3 & 0.45 & 0.13 & 2.3 & - & 10.05 \\
\hline ZnO & - & - & - & - & - & - & - & - & 99.6 & 0.1 \\
\hline
\end{tabular}

F.L: Fired loss

Table 2. Used recipes.

\begin{tabular}{|l|l|l|l|l|}
\hline Recipes & $\mathbf{1}$ & $\mathbf{2}$ & $\mathbf{3}$ & $\mathbf{4}$ \\
\hline Kaolin & 25 & 25 & 25 & 25 \\
\hline Albite & 30 & 29 & 27 & 25 \\
\hline Quartz sand & 5 & 5 & 5 & 5 \\
\hline Clay & 40 & 40 & 40 & 40 \\
\hline ZnO & - & 1 & 3 & 5 \\
\hline
\end{tabular}

\section{Results and Discussion}

\subsection{Physical Measurements}

The firing shrinkage increased up to $3 \% \mathrm{ZnO}$ addition, then decreased. In a study on the subject, it was found that the sintering degree increased with early sintering and consequently firing shrinkage and strength increased [21]. There is an increase up to $3 \% \mathrm{ZnO}$ addition in parallel with the increased sintering and firing shrinkage in the fired loss value. While the maximum value of the fired strength value was 400 $\mathrm{kg} / \mathrm{cm}^{2}$ in the standard body, it increased to $511 \mathrm{~kg} / \mathrm{cm}^{2}$ in the body with added $3 \% \mathrm{ZnO}$. The water absorption value also showed a value close to the standard $(0.05 \%)$ as $0.06 \%$ in the addition of $3 \% \mathrm{ZnO}$.

Table 3. Pysical characteristics of bodies.

\begin{tabular}{|l|l|l|l|l|}
\hline Recipes & $\mathbf{1}$ & $\mathbf{2}$ & $\mathbf{3}$ & $\mathbf{4}$ \\
\hline Fired Shrinkage (\%) & 6.45 & 7.75 & 8.45 & 7.80 \\
\hline Fired Lost (\%) & 3.9 & 4.9 & 5 & 4.1 \\
\hline $\begin{array}{l}\text { Dried Strength } \\
\left(\mathrm{kg} / \mathrm{cm}^{2}\right)\end{array}$ & 16.0 & 14.2 & 14.9 & 16.7 \\
\hline $\begin{array}{l}\text { Fired Strength } \\
\left(\mathrm{kg} / \mathrm{cm}^{2}\right)\end{array}$ & 400 & 498 & 511 & 471 \\
\hline Water Absorpsition \%) & 0.05 & 0.13 & 0.06 & 0.05 \\
\hline
\end{tabular}

Table 4. Aritmetic mean, variance and standard deviation of measurements

\begin{tabular}{|l|l|l|l|}
\hline & $\boldsymbol{\mu}$ & $\boldsymbol{\sigma}^{\mathbf{2}}$ & $\boldsymbol{\sigma}$ \\
\hline Viscosity (sn) & 57 & 191.3 & 13.83 \\
\hline Fired Shrinkage (\%) & 7.61 & 0.70 & 0.83 \\
\hline Fired Lost $(\%)$ & 4.47 & 0.31 & 0.55 \\
\hline Dry Strength $\left(\mathrm{kg} / \mathrm{cm}^{2}\right)$ & 15.45 & 1.24 & 1.11 \\
\hline Fired Strength $\left(\mathrm{kg} / \mathrm{cm}^{2}\right)$ & 470 & 2455 & 49 \\
\hline Water Absorbtion $(\%)$ & 0.07 & 0.001 & 0.04 \\
\hline
\end{tabular}

$\mu=$ aritmetic mean, $\sigma 2=$ variance, $\sigma=$ standard deviation

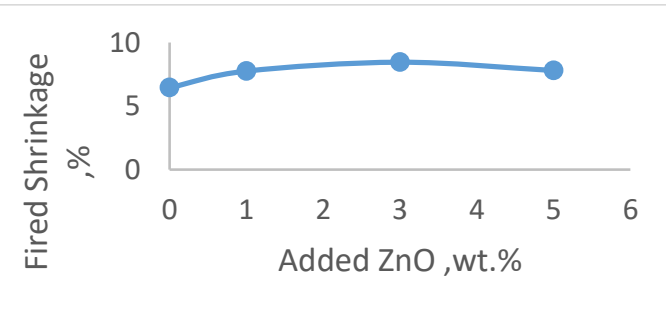

Figure 1. F. shrinkage \% - added $\mathrm{ZnO}$ wt.\% graphic.

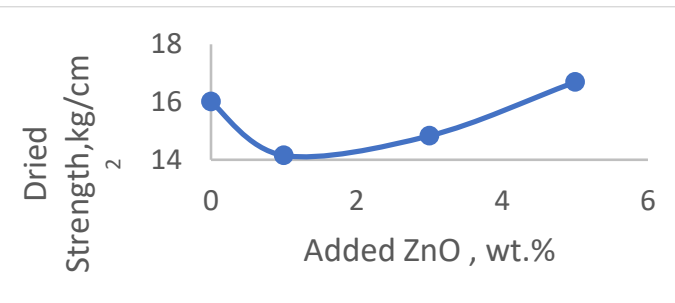

Figure 2. Dried strength- added $\mathrm{ZnO}$ wt.\% graphic.

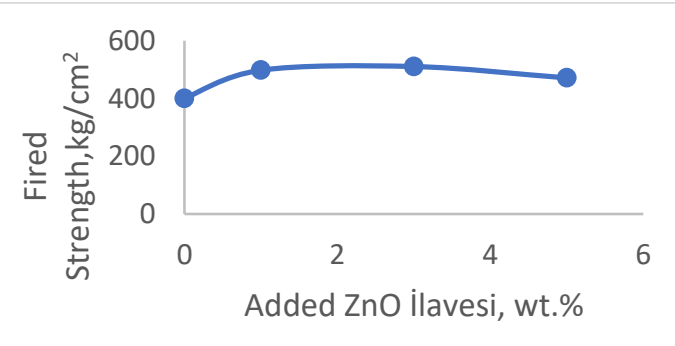

Figure 3. Fired strength - added $\mathrm{ZnO}$ wt.\% graphic.

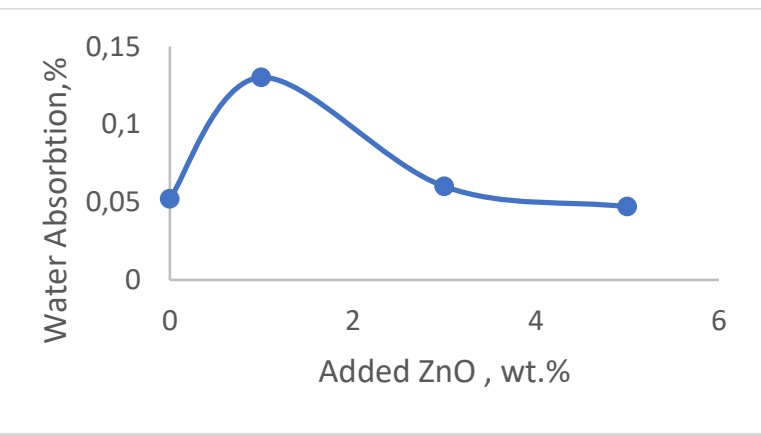

Figure 4. Water absorbtion \% - added $\mathrm{ZnO}$ wt.\% graphic 
Physical characteristics of bodies are shown in Table 3. All trials meet the requirement of maximum $0.5 \%$ according to ISO 10545-3 water absorption standard and minimum $350 \mathrm{~kg} / \mathrm{cm}^{2}$ according to ISO $10543-5$ bending strength requirement. The increase in firing shrinkage and fired strength and the decrease in water absorption by using $\mathrm{ZnO}$ up to $3 \%$ is an indication that it has a positive effect on sintering. It has been determined that the addition of $\mathrm{ZnO}$ increases the viscosity of the slurry, that is, it impairs the relogical properties.

\subsection{Microstructural Analyses}

The SEM images of the standard and 3wt.\% $\mathrm{ZnO}$ added samples are shown in Figure 5.1.a.b.c and Figure 5.2.a.b.c.

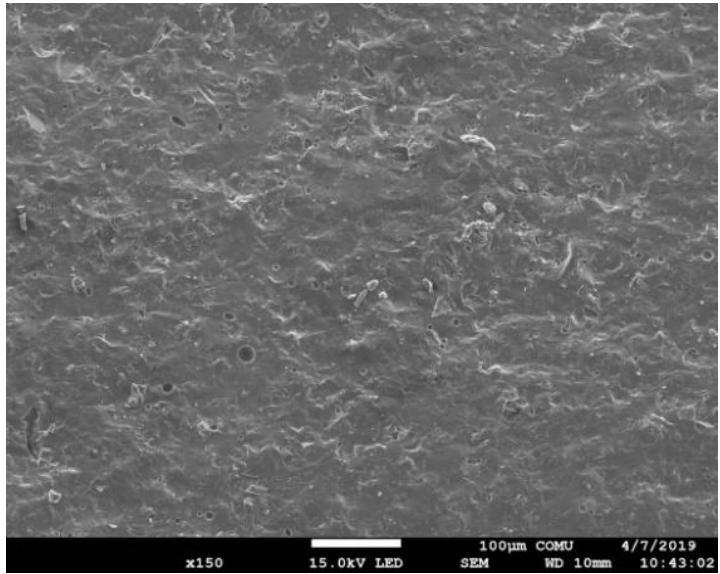

a

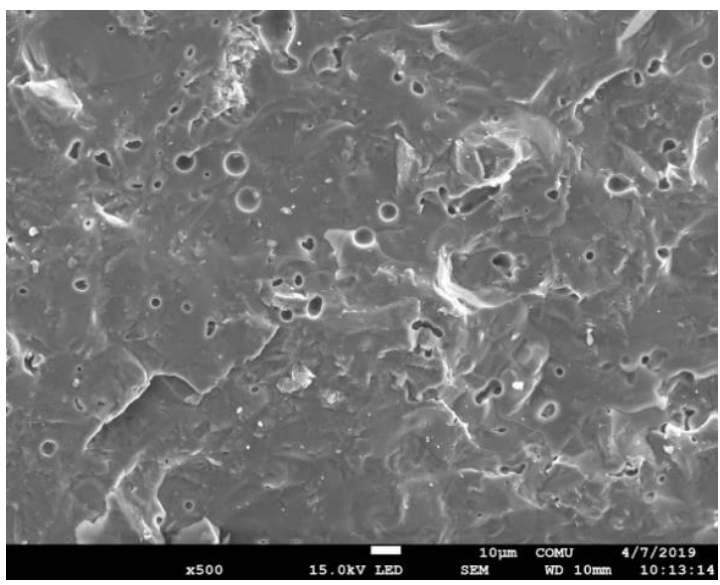

b

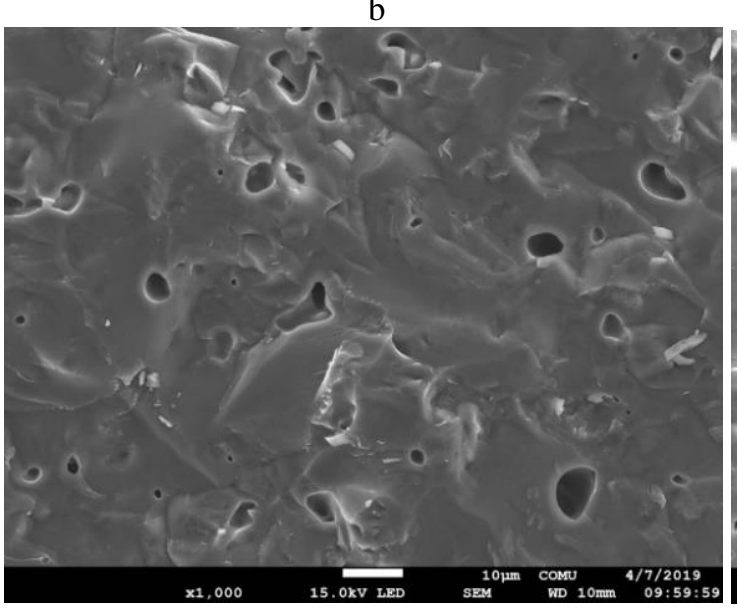

c

1

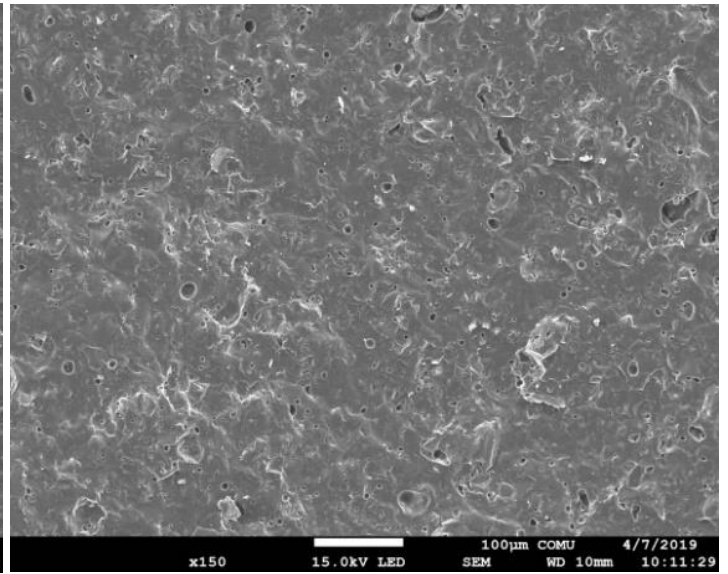

a

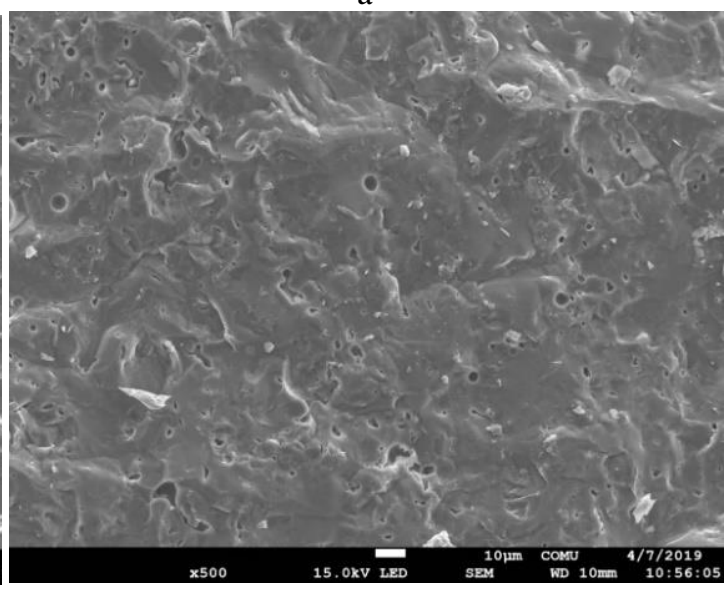

b

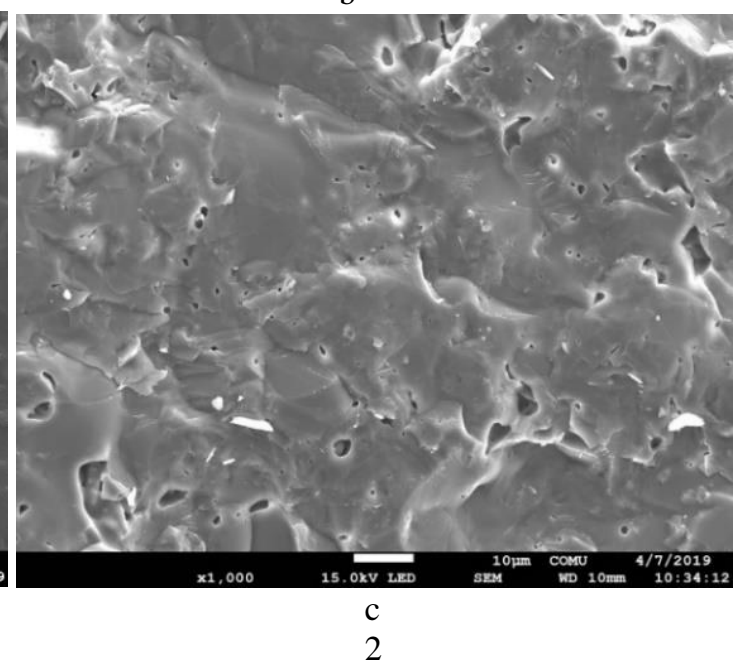

Figure 5.1.a.b.c SEM images of standard sample

Figure 5.2.a.b.c Added 3 wt. ZnO sample's SEM images. 
There is a decrease in the size of the pores on the fractured surface that shows close pores in the recipe 3 as seen at 500x and $1000 \mathrm{x}$ magnification. Pore sizes decrease according to feret diameter measurements. The lower the temperature of the liquid phase formation with eutectic reactions $\left(\mathrm{Na}_{2} \mathrm{O}-\mathrm{K}_{2} \mathrm{O}-\mathrm{ZnO}-\mathrm{Al}_{2} \mathrm{O}_{3}-\mathrm{SiO}_{2}\right)$, the more positively it contributes to rapid firing[22]. The viscosity of the glassy phase should also be at an optimal level, which is high enough not to cause pyroplatic deformation, but low enough to respond easily and quickly to gas release. High level of glass phase formation is observed in both body types. Another reason for the increase in strength is that the closed pore volume decreases due to the positive effect of $\mathrm{ZnO}$ on sintering. As seen Figure 6 and Figure 7 for EDX analyses, both standard and doped samples have high vitrification. Alkali metals and zinc were detected in the quartz base amorph matrix in the analysis performed on the sample added $\mathrm{ZnO}$ that is no.3. Zinc has diffused into the glassy matrix by showing its melting property. One reason for the increase in strength is thought to be the change in glassy matrix composition. The presence of carbon element in EDX analysis indicates short firing time that cannot provide enough time for organics to escape. In a study performed on stoneware tiles, $\mathrm{C}$ element was not found in EDX analysis of the standard sample [23].
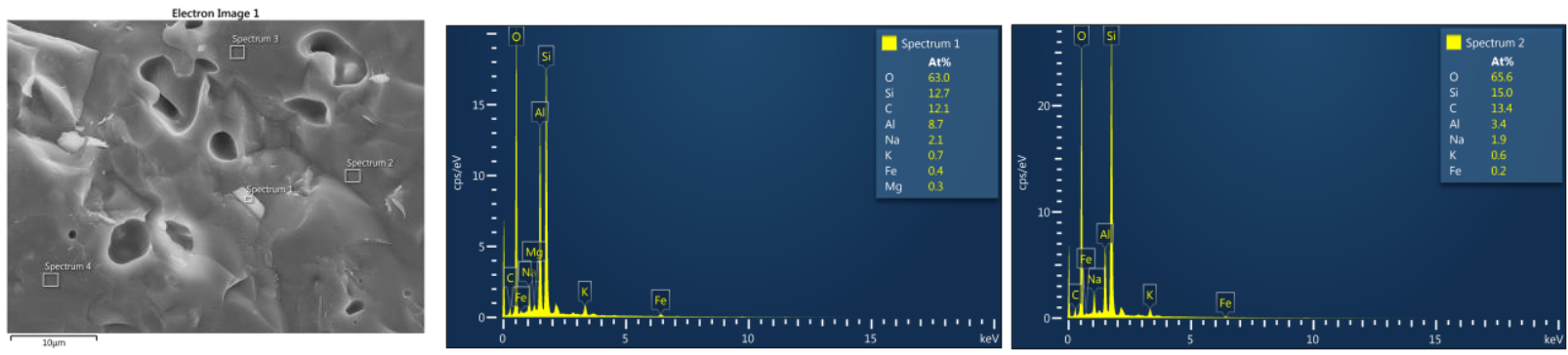

Figure 6. Standard ( 1 no ) sample's EDX images.
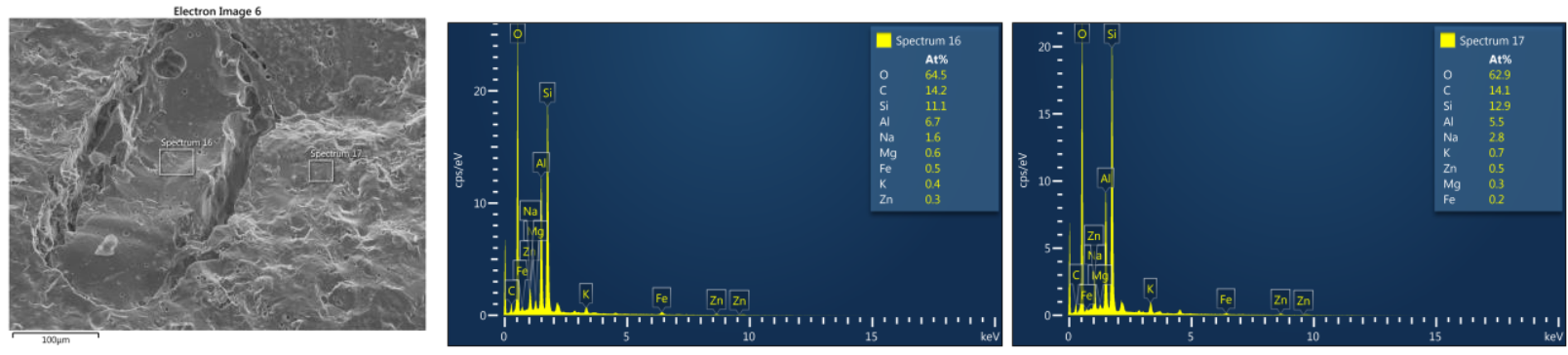

Figure 7. 3 wt. \% added $\mathrm{ZnO}$ ( no 3) sample's EDX images.

\subsection{Crystalline Phase Analyses}

The XRD graphics of the standard and 3wt. \% added $\mathrm{ZnO}$ samples are shown in Figure 8. Rietveld method was used for quantatative analyzes. The presence of $\mathrm{ZnO}$ in the ceramic body decreased the viscosity of the liquid phase and increased the solubility of quartz by increasing its chemical activity; spinel phase was occured, mullitization was prevented and albite formation was triggered. While quartz in the standard body was $77.2 \%$, mullite $22.8 \%$, in body no.3, quartz was $56.4 \%$, cristobalite $2.5 \%$, spinel $27.4 \%$ and albite $13.8 \%$. It has been observed that the addition of $\mathrm{NiO}$ also creates a spinel phase [13]. In the study conducted by Chaudhuri, it was observed that with the addition of 4 wt.\% $\mathrm{ZnO}$ to the porcelain body, a minimum of mullite was formed[16] .With increasing quartz solubility, increased the amount of quartz in the glassy phase and thus cristobalite formation was observed in XRD [8]. In a study, it was determined that the addition of $\mathrm{ZnO}$ to the household porcelain body creates cristobalite and increases with the amount of $\mathrm{ZnO}$ added. In the same study, it was observed that the amount of quartz decreased [21]. 


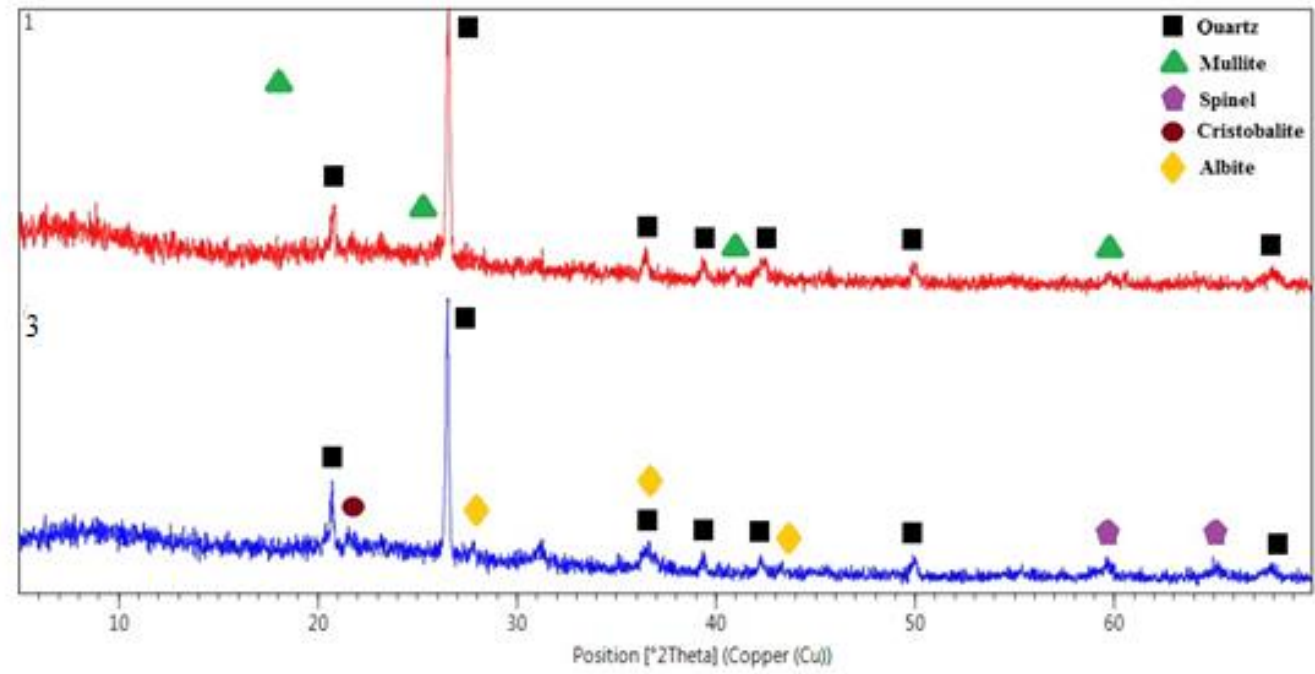

Figure 8. Standard (1) and $3 \mathrm{wt} . \% \mathrm{ZnO}$ added sample (3).

\subsection{Colour Analyses of the Samples}

Colorimeter values of bodies are shown in Table 5. As a result of colorimeter measurements, it was determined that the L (lightness) value increased, a (redness) and b (yellowness) values decreased and -a value (green) increased with increasing $\mathrm{ZnO}$. Especially in the $5 \% \mathrm{ZnO}$ sample, the value of a decreases from 3.91 to 0.30 compared to the standard. L (lightness) value increases with increasing $\mathrm{ZnO}$. With increased $\mathrm{ZnO}$, the (yellowness) value of $\mathrm{b}$ decreased by $1 \%$ and reached the smallest value with $5 \%$ added value. When $\Delta \mathrm{E}<1$, the human eye cannot detect color difference. According to this, the color change that occurs in all doped samples can be detected by the human eye. Fired samples are shown in Figure 9.

Table 5. Colorimeter degrees of bodies.

\begin{tabular}{|l|l|l|l|l|}
\hline Sample & L & a & b & $\Delta \mathbf{E}$ \\
\hline $\mathbf{1}$ & 47.75 & 3.91 & 15.31 & Std. \\
\hline $\mathbf{2}$ & 48.61 & 3.99 & 11.68 & 3.73 \\
\hline $\mathbf{3}$ & 50.41 & 2.53 & 12.31 & 4.24 \\
\hline $\mathbf{4}$ & 54.68 & 0.30 & 10.60 & 9.1 \\
\hline
\end{tabular}
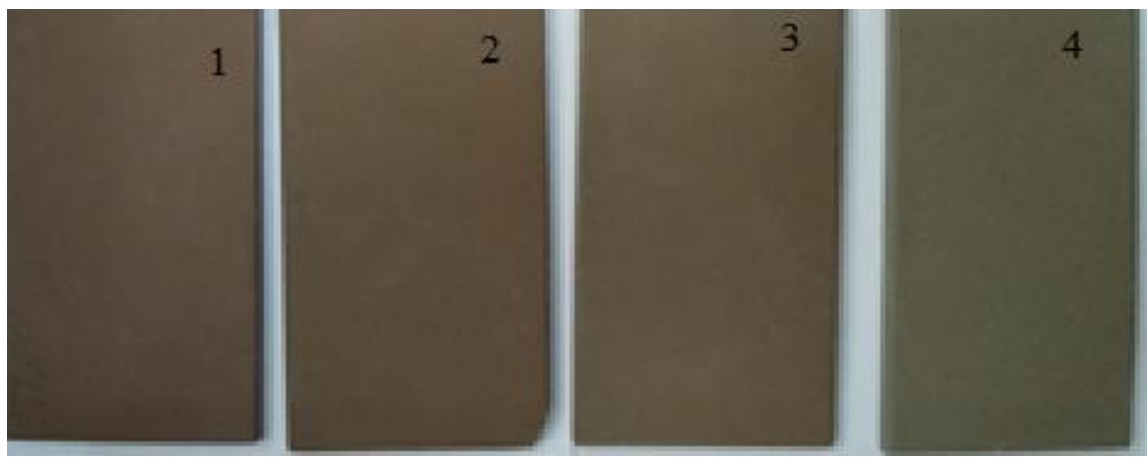

Figure 9. Images of fired bodies.

\section{Conclusion}

According to study,

1. It has been determined that the added of $3 \mathrm{wt} . \% \mathrm{ZnO}$ increased the strength increase from $400 \mathrm{~kg} / \mathrm{cm}^{2}$ to 511 $\mathrm{kg} / \mathrm{cm}^{2}$, respectively, as standard and added samples. 2. While there was quartz $77.2 \%$ and $22.8 \%$ mullite in the standard body, $56.4 \%$ quartz, $2.5 \%$ cristobalite,
$27.4 \%$ spinel and $13.8 \%$ albite were detected in $3 \%$ $\mathrm{ZnO}$ added body. With the addition of $3 \% \mathrm{ZnO}$, the liquid phase viscosity decreased and the amount of quartz in the body decreased, and the formation of cristobalite was triggered by the increasing amount of quartz in the liquid phase. Mullite formation was prevented and spinel phase formed. 
3. It was determined that the $\mathrm{L}$ (openness value) value of the standard sample and the $5 \% \mathrm{ZnO}$ added sample increased from 47.75 to 54.68. The values where a (redness) and b (yellowness) value are the smallest and the values that falls according to the standard are a: 0.3 and $\mathrm{b}: 10.70$ in the $5 \%$ added $\mathrm{ZnO}$.

In the production of wall tiles and sanitaryware, studies can be carried out on the use of $\mathrm{ZnO}$ in recipes to determine the effect of different compositions and firing times. The benefit / cost parameter can be revealed in a detailed work.

\section{Author's Contributions}

Savaş Elmas: Drafted and wrote the manuscript, performed the experiment and result analysis.

\section{Ethics}

There are no ethical issues after the publication of this manuscript.

\section{References}

TSF2019

Faaliyet

Raporu. https://serfed.com/upload/raporlar/TSF\%202019\%20FAAL\%C4\%B0 YET\%20RAPORU\%20SON.pdf (accessed at 15.10.2020)

2. Paganelli M. and Sighinolfi D., 2009.Effect of Quartz Particle Size on Porcelain Stoneware Sintering by Means of Optical Dilatometry. Ceramic Forum International, Volume 86.

3. Biesuz, M., Abate W.D., Sglavo V., 2018. Porselem stoneware consolidation by flash sintering. Journal of American Ceramic Society, Volume 101, pp.71-81.

4. Mahdi O.S., 2018. Study the Influence of Sintering on the Properties of Porcelain Stoneware Tiles. International Journal of Applied Engineering Research ISSN 0973-4562 Volume 13, Number 6, pp. 3248-3254.

5. Zanelli C., Raimondo M., Guarini G. and Dondi M., 2011. The vitreous phase of porcelain stoneware: Composition, evolution during sintering and physical properties. Journal of Non-crystalline Solids, Volume 357, pp. 3251-3260.

6. Fortuna D., 2000, Ceramic Technology-Sanitaryware. Gruppo Editoriale Faenza Editrice.

7. Ryan W., Radford C., 1987. Whitewares Productions, Testing and Quality Control. The Institute of Ceramics, Pergamon Press.

8. Lundin S. T., 1964. Microstructure of Porcelain pp.93-106 in Microstructure of Ceramic Materials, Proceedings of the American Ceramic Society Symposium, National Bureau of Standards Miscellanesous Publications No.257. National Bureau of Standard, Gaithersburg, MD

9. Vari A. Drying and Firing of Ceramic Tiles, Modena-Italia S.A.L.A.srl, via carlo Zucchi,21 A/B.

10. Worral W.E., 1975. Clay and Ceramic Raw Materials, New York, Elsevier Applied Science Publishers.

11. Norton F.H., 1970. Fine Ceramics Technology and Applications,Florida, Robert E.Krieger Publishing Comp,INC.
12. Iqbal Y., Lee W. E., 2000, Microstructural Evolution in Triaxial Porcelain, J.Am. Ceram. Soc., 83 [12] 3121-27.

13. Bhattacharyya S., Snehesh T.S., 2015. Improvement of fired properties in porcelain system by the addition of transition metal oxides, Journal of The Australian Ceramic Society, Volume 51[1], 815

14. Bhattacharya S., Snehish T.S., 2015. Effect of cobalt oxide additive on the fired properties of tri-axial ceramic, Ceramics International 41, 61-67.

15.Bhattacharyya S., Das S.K., Mitra N.K., 2005. Effect of titania on fired characteristics of triaxial porcelain, Bull. Mater. Sci., Vol. 28, No. 5, August, pp. 445-452. (C) Indian Academy of Sciences.

16.S.P., 1974. Ceram.Bull.53, 169

17. Iya S.G.D, Noh M.Z., Razak S.N.A., Sharip N., Kutty A.A., 2019. Effect of Iron (111) Oxide $\left(\mathrm{Fe}_{2} \mathrm{O}_{3}\right)$ as an Additive and Substitution of Quartz with POFA on Physico- Mechanical Properties of Porcelain. International Journal of Nanoelectronics and Materials Volume 12, No.2, Apr 175-1847.

18. Tulyaganov D.U., Agathopoulos S., Fernandes H.R., Ferreira J.M.F., 2006. Influence of lithium oxide as auxiliary flux on the properties of triaxial porcelain bodies. Journal of the European Ceramic Society, 26 1131-1139.

19.Chaudhuri S.P., Sarkar P., 1995. Constitution of Porcelain Before and After Heat-Treatment. I: Mineralogical Composition, Journal of the European Ceramic Society, 15 1031-1035.

20. Kong L.B., Huang H., Zhang T.S., Gan Y.B., Ma j., Boey F., Zhang R.F., 2003. Effect of transition metal oxide on mullite whisker formation from mechanochemically activated powders. Materials and Engineeering, A359 75-81.

21. Maslenikova G.N., Stoikova T.V., 2001. Household Porcelain with Mineralizing Additrives. Glass and Ceramics, Vol.58, Nos 7-8.

22. Carrty William M., Senepati U., 1998. Porcelain-Raw Materials, Processing, Phase Evolution, and Mechanical Behaviour. J.Am.Ceramic. Soc,. 81[1] 3-20.

23. Selli N.T., 2015. Investigation of the Whiting Composition for the Porcelain Stoneware Tiles. Acta Physica Polonica A Vol.127 12021204 